Journal of Life Economics

Cilt / Volume 6, Say1 / Issue 1, 2019, pp. 11-20

E - ISSN: 2148-4139

URL: http://www.ratingacademy.com.tr/ojs/index.php/jlecon

DOİ: $10.15637 /$ jlecon.6.002

Araştırma Makalesi/Research Article

\title{
EVALUATING THE LABOR'S PRODUCTIVITY: DISCIPLINE, WORK PASSION AND WORK ACHIEVEMENT
}

\author{
Anak Agung Ngurah Gede Sadiartha* \& Sunday Ade Sitorus** \\ *Lecture of Economic Faculty, University of Hindu Indonesia (UNHI) Denpasar, INDONESIA, \\ E-mail: sadiartha.unhi@gmail.com, ORCID ID: https://orcid.org/0000-0002-1497-1735 \\ **Lecturer at the Department of Management, STIE ITMI, Medan, INDONESIA, \\ E-mail: sundayadecoms@gmail.com, ORCID ID: https://orcid.org/0000-0003-3107-5534
}

Received: 18 October 2018; Accepted: 12 January 2019

\begin{abstract}
Duties and responsibilities must be accompanied with discipline, work passion and work achievement, where productivity at work is measurable and can potentially boost company's profitability in the future. The aim of this research is to investigate the influence of discipline, work passion and work achievement on labor's productivity in the City of Medan. The results of the research found that the variables of discipline and work passion failed to show an optimal result whereas the variables of work achievement and labor's productivity show an optimal result. The analysis on discipline partially does not provide positive and significant influence on labor's productivity at the company but causes loss for the company. The analysis on work passion partially does not provide positive and significant influence on work productivity at the company but causes loss for the company. An analysis on work achievement partially provides positive and significant influence on work productivity in the company and causes an advantage for company when workers show good work achievement, by which $45.7 \%$ of work achievement is very expected. The analysis on independent variables of discipline, work passion and work achievement discovered simultaneous influence on labor's productivity.
\end{abstract}

Keywords: Discipline, Work Passion, Work Achievement, Labor's Productivity.

JEL Codes: J01, J82

\section{INTRODUCTION}

Each company or organization has their own goals and objectives. In order to achieve these goals and objectives, the labors are required to show higher level of professionalism and responsibility for the work performed. The objectives of a work in an organization should be clearly and ideally defined and pose a challenge for workers so that they can solve the problems (Yunita, 2017). This means that the objectives of a work that must be achieved by an employee 
should be accorded with labors' capability, thus the duties can be performed seriously and with discipline. When the duties imposed on labors are beyond their capability, the workers' seriousness and discipline become low, for example the duties for workers with high school diploma are assigned to the workers with bachelor's degree diploma. This will definitely cause the labors less disciplined in carrying out the duties. In order to carry out the duties, each of the labors must have work passion in fulfilling their own duties and responsibilities (Roziqin,2010). Work passion can be defined as a simple statement from varied psychological forces in relation to their work. Work passion can be interpreted as a work climate or workplace atmosphere in an organization that brings excitement in carrying out work and encourage them to work more and more productive (Darwaman, 2008). For 25 years, labor's productivity in Indonesia grew by $3.1 \%$ per year. Meanwhile, the Conference Board data in Total Economy Database recorded productivity per Indonesian workers in 2017 by US\$ 24.6 thousand (www.detikfinance.com). In an effort to take advantage of existing human resources in an effective and efficient manner, good personnel management is required since humans are social creatures who have different characteristics and behavior, needs different from other production factors. The efforts in improving employees' quality and behavior in general is aimed at the effort of enhancing employee's productivity with work passion. Beer, et al (Suhariadi, 2002) point out that all forms of increased productivity will not be able to provide maximum results when employees have no work passion in performing their tasks and the work more vigorously until the work is expected to be completed more quickly and better. In this case, work passion is a mental condition that reflects the feelings of a person in performing work individually and in group. The shall result in the increased and better human resources competence. In general, each company or organization expects its employees to work well and exhibit high labor productivity. This can be achieved only if each of its employees has the skills and high work productivity. With high labor productivity, the employees will always work well which in the end will achieve and accomplish the company's goals.

\section{LITERATURE REVIEW}

\section{Discipline}

According to Budiono (2006), discipline is an attitude or behavior that illustrates the compliance towards a regulation or provisions. Discipline also means a demand for the sustainability of similar, organized and orderly life, which are made as requirements for the continuation of a development and changes towards betterment. According to Slamet (2007: 215) discipline is derived from the word "disciple" which means to learn. Work discipline according to Robbins (in Slamet, 2004) can be defined as an attitude and behavior performed on a voluntary basis with full awareness and willingness to follow the rules that have been set by the organization or superiors, either in writing or oral.

\section{Work Passion}

According to Hasibuan, work passion is the desire and the seriousness of someone in performing his work effectively and with discipline in order to achieve maximum productivity. Hence, it can be concluded that work passion is employees' attitude who work with more optimal conditions that reflect the situation of where the company can achieve expected goals. With high work passion with other words can work with better results, then the spirit of the work had an effect on the activity of the company so that the company or organization wants employees who have high spirit (R.Y. Sangki., et al. 2014). Work passion is the desire and the seriousness of the person in performing duties effectively and with discipline in order to achieve maximum work results (Hasibuan, 2008). 


\section{Work Achievement}

According to Mangkunegara (2008), work achievement is "the work results in quality and quantity achieved by an individual who carry out their tasks in accordance with the responsibility imposed on him.

\section{Labor's Productivity}

Hasibuan (2005) put forth that in a simpler manner, productivity is a comparison of quantity between the number produced and the amount of each source used during the production of progress. Simamora (2004) the factors used in the measurement of the workforce productivity includes work quantity, work quality and timeliness.

\section{RESEARCH METHODOLOGY}

This research uses a descriptive approach with quantitative research method survey, a research that take samples from a population and uses the questionnaires (Ghozali,2005) as data collection instrument. The data were collected using instrument distribution of questionnaires, which is for the requirement of data processing under linear regression which is statistical method that allows us to summarize and study relationships between two continuous (quantitative) variables. The data were collected from all of the population as the sample of respondents as many as 2074 questionnaires. Hence, the size of the sample in this research is taken from the population of 547.265 labors in the City of Medan, by taking the error level (d) of $5 \%$ and using slovin formula, the samples of respondents are 2074.

\section{ANALYSIS AND DISCUSSION}

Table 1. Validity and Reliability Test Results

\begin{tabular}{lll}
\hline Variables & Conclusion & \\
\hline Discipline & Valid & Reliable \\
Work Passion & Valid & Reliable \\
Work Achievement & Valid & Reliable \\
Labor Productivity & Valid & Reliable \\
\hline
\end{tabular}

The value of corrected item-total correlation of all question items for the variables of discipline, work passion and work productivity is greater than 0,361 . Thus, it can be concluded that the question item is valid. The value of Cronbach's Alpha from each of the research variables show value bigger than 0.60 , this means that the questionnaire item from each of the variables is reliable.

\section{Descriptive Statistics}

Descriptive Statistics provides an overview of standard deviation data used in research. The following is a general statistical data from all data used in table 1 below: 
Table 2. Descriptive Statistics

\begin{tabular}{|l|l|l|l|}
\hline & Mean & Std. Deviation & N \\
\hline $\mathrm{y}$ & 29.21 & 5,203 & 1370 \\
$\mathrm{x} 1$ & 31.15 & 1,770 & 1370 \\
$\mathrm{x} 2$ & 31.75 & 5,778 & 1370 \\
$\mathrm{x} 3$ & 31.49 & 4,265 & 1370 \\
\hline
\end{tabular}

Source: Processed Data, 2017

Table 1 shows that the average discipline is 31,15 with standard deviation of 1,770 . An average work passion is 31,75 with standard deviation of 5,778. It can be concluded that the data are varied enough and spread between the minimum and maximum values. The average work achievement is 31,49 with standard deviation 4,265. It can be concluded that the data are varied enough and spread between the minimum and maximum values.

\section{Multiple Linear Regression Model}

This research uses multiple linear regression equation. The following is a double linear regression coefficient Table:

Table 3. Regression Coefficient Test Results

\begin{tabular}{|c|c|c|c|c|c|}
\hline \multirow[t]{2}{*}{ Model } & \multicolumn{2}{|c|}{$\begin{array}{l}\text { Unstandardized } \\
\text { Coefficients }\end{array}$} & \multirow{2}{*}{$\begin{array}{l}\text { Standardized } \\
\text { Coefficients }\end{array}$} & \multirow[t]{2}{*}{$T$} & \multirow[t]{2}{*}{ Sig. } \\
\hline & B & Std. Error & & & \\
\hline \multirow[t]{4}{*}{ (Constant) } & 25,391 & 2,655 & & 9,564 & .000 \\
\hline & -.056 & 082 & -.019 & -.675 & .500 \\
\hline & .021 & .025 & .023 & .816 & .415 \\
\hline & .156 & .033 & .127 & 4,750 & .000 \\
\hline
\end{tabular}

Source : Processed Data, 2018

Based on Table 2 above, multiple linear regression obtained the following equation:

$$
\mathrm{Y}=\mathbf{2 3}, 391-0,056 \mathrm{X}_{1}+\mathbf{0 , 0 2 1} \mathrm{X}_{2}+\mathbf{0 , 1 5 6 X _ { 3 }}
$$

\section{Description:}

1. Constanta value $(a)=25.391$. This constantan value shows that when the independent variables of discipline and work passion are considered constant, then the average labor's productivity at the company is 25,391 or $25.4 \%$

2. Discipline (X1) has a negative regression coefficient of 0,056 . This shows that the value of labor's discipline is below the average, that when the discipline decreases by 1 point and it will decrease labor's productivity by 0.056 or $5.6 \%$

3. Work Passion (X2) has a positive regression coefficient of 0,021 . This shows that every increase of capital structure value by 1 (one) time, it will increase labor's productivity at the company by $2.1 \%$ or 0,021

4. Work achievement (X3), has a positive regression coefficient of 0,156 . This shows that every increase of labor's productivity by 1 (one) time at the company is $15.6 \%$ or 0,156 and has a significant is 0,000 
On the multiple linear regression equation above, the most dominant in labor's productivity in the company is work achievement due to the fact that it has a larger coefficient value compared with other variables.

\section{Coefficient of Determination $\left(\mathbf{R}^{2}\right)$}

The value of the influence of independent variables on dependent variables is determined using coefficient of Determination (R2) test as follows:

Table 4. Results of Coefficient of Determination

\begin{tabular}{|l|l|l|l|l|}
\hline Model & R & R Square & It said the R Square & Std. Error of the Estimate \\
\hline 1 & .130 & .017 & .015 & 5,165 \\
\hline
\end{tabular}

Source: Processed Data, 2018

Based on table 3, it can be seen that the value of Adjusted $R^{2}$ is 0.015 . This shows that 1.5 percent of variation of the variable of labor's productivity (Y) can be explained by the variation of the variable of discipline $\left(\mathrm{X}_{1}\right)$ and Work Passion $\left(\mathrm{X}_{2}\right)$, Work Achievement $\left(\mathrm{X}_{3}\right)$, whereas the remaining $(100 \%-1.5 \%=99.5 \%)$ is a variation of another variable beyond explanation in the present study.

\section{F Test (Simultaneous)}

Table 5. Results of Simultaneous F Test

ANOVA $^{\mathrm{a}}$

\begin{tabular}{|ll|l|l|l|l|l|}
\hline Model & Sum of Squares & df & Mean Square & F & Sig. \\
\hline \multirow{3}{*}{$\begin{array}{lllll}\text { Regression } \\
\text { A Residual }\end{array}$} & 625,320 & 3 & 208,440 & 7,814 & $.000^{\mathrm{b}}$ \\
& Total & 36439.807 & 1366 & 26,676 & & \\
\hline
\end{tabular}

a. Dependent Variable: y

b. Predictors: (Constant), x3, x2, x1

Source : Processed Data, 2017

The results of $\mathrm{F}$ Test displayed in table 4 above shows that the value of $\mathrm{F}_{\text {count }}$ is 7,814 and using the Table $F$, it obtained the value of $F_{\text {the table }}$ of 2.61. Then the result is $F_{\text {count }}>F_{\text {table }}$ $(7,814>2,61)$ with significant level of 0.00 (smaller than 0.05 ). This shows that the results of research hypothesis accepts $\mathrm{H}_{a}$ and rejects $\mathrm{H}_{0}$ which thus means that the independent variables of discipline, work passion and work achievement have simultaneous influence on labor productivity. 


\section{T-test (Partial)}

Table 6. T-Test

\begin{tabular}{|l|l|l|l|l|l|}
\hline \multirow{2}{*}{ Model } & \multicolumn{2}{|l|}{ Unstandardized Coefficients } & $\begin{array}{l}\text { Standardized } \\
\text { Coefficients }\end{array}$ & T & Sig. \\
\cline { 2 - 4 } & $\mathrm{B}$ & Std. Error & Beta & & \\
\hline (Constant) & 25,391 & 2,655 & & 9,564 & .000 \\
$\mathrm{x} 1$ & -.056 & .082 & -.019 & -.675 & .500 \\
$\mathrm{x} 2$ & .021 & .025 & .023 & .816 & .415 \\
$\mathrm{x} 3$ & .156 & .033 & .127 & 4,750 & .000 \\
\hline
\end{tabular}

Source : Processed Data, 2017

Based on the results of $t$ statistics test on table 5, the following matters can be explained:

1. The influence of work discipline on labor's productivity

The variable of Work Discipline has $t_{\text {count }}-0,675$ and $t_{\text {table }}$ of 1.96. Then the $t_{\text {count }}<t_{\text {table }}$ $(-0,675<1.96)$ with significant value $0.5>0.05$. This shows that $H_{a}$ is rejected and $H_{0}$ is accepted which means that partially, discipline does not provide positive and significant influence on labor's productivity at the company but causes loss for the company.

2. The influence of work spirit on labor's productivity

The variables of work passion has $t_{\text {count }}$ of 0,861 and $t_{\text {table }}$ of 1.96 . Therefrom, the $t_{\text {count }}$ $<t_{\text {table }}(0,861<1.96)$ with significant value $0.415>0.05$. This shows that $\mathrm{H}_{\mathrm{a}}$ is rejected and $\mathrm{H}_{0}$ is accepted which thus means that partially, work passion does not provide positive and significant influence on work productivity at the company, instead causes loss for the company.

3. The influence of work achievement on labor's productivity

The variable of work achievement has $t_{\text {count }} 4,750$ and $t_{\text {table }}$ of 1.96. Then $t_{\text {count }}>t_{\text {table }}$ $(4,750>1.96)$ with significant value $0.000<0.05$. This shows that $H_{a}$ is accepted and $H_{0}$ is rejected which means that partially, work achievement provides positive and significant influence on work productivity at the workplace but this brings an advantage to the company when workers have good work achievement, which is $45.7 \%$ as highly expected.

\section{CONCLUSION}

The above discussions lead to the following conclusions:

1. Based on the descriptive analysis, it was discovered that the variables of discipline and work passion have yet shown an optimal result, whereas the variables of work achievement and labor's productivity shows an optimal result.

2. The analysis on discipline partially does not provide positive and significant influence on labor's productivity at the company but causes loss for the company.

3 . The analysis on work passion partially does not provide positive and significant influence on work productivity at the company but causes loss for the company.

4. Based on the analysis, work achievement partially has positive and significant influence on labor's productivity at the workplace and brings an advantage to the company when workers display good work achievement, which is $45.7 \%$ as expected.

5. Based on the analysis, the variable of discipline, work passion and work achievement have simultaneous influence on labor productivity. 
6. Based on this research my scientific knowledge allows us to develop new roles of discipline, work passion and work achievement, solve practical problems, and make informed decisions - both individually and collectively. Because discipline, work passion and work achievement are so useful, the process of science is intertwined with those applications: in my New scientific knowledge may lead to new applications.

7. In this research paper we have examined different discipline, work passion and work achievement systems in Indonesia and the international. Variations exist in terms of financing, provider payment mechanisms, and the role of government, including the degree of centralization. The International stands out of as the country with the highest expenditures on discipline, work passion and work achievement. Many characterize the main gap in the Indonesia system as the problem of the uninsured. While this does not mean that they go entirely without care, the uninsured consume only half as much discipline, work passion and work achievement on average as the insured. 


\section{REFERENCES}

Alex S. Nitisemito, (2005). Personnel management, Graha Indonesia, Jakarta

Arikunto, Suharsimi, (2006), Management Teaching Humanely, PT Rineka Copyright Notice

Darmawan,.(2008). Basic Human Needs. Jakarta : Salemba Medika

Dharma, Surya (2005.) Labor's productivity Management. Pustaka Pelajar, Jakarta

Tachrir Fathoni, Abdurrahmat, (2006). Human Resources Organization and Management, Publisher Rineka Copyright, Jakarta.

Ghozali, Imam, H. (2005). Multivariat Analysis using SPSS Program. Publisher Diponegoro University. Semarang

Hadari Nawawi, et.al. (2006). Effective leadership. Yogyakarta : UGM Press

Handoko, Hani (2010) Personnel Management \& Human Resources, Second Edition,BPFE UGM Yogyakarta

Haris Budiono and Amirullah, (2004). Introduction to management. Second print. Graha Ilmu, Yogyakarta

Hasibuan, Malayu, SP., (2007), Human Resources Management, Revised edition, Earth characters, Jakarta

Mangkunegara, Anwar Prabu, (2007), Evaluation of the productivity of the work of Human Resources, Third Print Publisher PT. Refika Aditama, Bandung

Mangkunegara, Anwar Prabu, (2008) Corporate Human Resources Management, Publisher PT, Adolescents Rosdakarya, Bandung

Moenir, (2008). The management of public services in Indonesia. The earth characters. Jakarta

Nurhayati, Dina (2008), The Influence of Leadership Style and Climate Change work Against Employee Productivity Handicraft Company AKP CRAFT Bantul. The State University of Yogyakarta

Prawirosentono, Suryadi. (2008). Policy on Employee Productivity. BPFE Yogyakarta.

Roziqin, Muhammad Zainur. (2010). Job satisfaction. Malang: Averroes Press.

Robbins, Stephen, P. (2008), Organizational Behavior. New Jersey :Prentice Hall International, Inc.

Santoso, Slamet, (2004) Group Dynamics, the earth characters, Jakarta

Schuler \& Jackson, (2007). Human Resources Management. PT. Raja Grafindo Persada, Jakarta

Siagian, Sondang. (2005). Human Resources Management. The Edition 1. Jakarta: Bumi Aksara.

Simamora, Henry.( 2006). Human Resources Management, STIE YKPN. Yogyakarta

Soekidjo Notoatmodjo. (2009). Human Resources Development. Copyright Rineka, Jakarta

Timple, A.Dale. (2005), Leadership and Human Resources Management : PT Elex Media Komputindo, Jakarta

Tu'u, Tulus. (2004). The role of Discipline in Students' Behavior and Performance. Grasindo Jakarta 
Wirawan.(2009) Evaluation of Human Resources Labor's productivity : Application Theory and Research. Jakarta: Salemba Empat

Yunita. (2017), in 25 Years, Indonesian's Worker Productivity Rose by 3.1\%, derived from https://finance.detik.com/berita-ekonomi-bisnis/d-3901770/dalam-25-tahunproduktivitas-pekerja-ri-naik-31, on 12 October 2017 
GEDE SADIARTHA \& ADE SITORUS / Evaluating the Labor's Productivity: Discipline, Work Passion and Work Achievement 